http://dx.doi.org/10.11646/phytotaxa.153.1.2

\title{
Knufia aspidiotus sp. nov., a new black yeast from scale insects
}

\author{
FAN HE ${ }^{1,2 \#}$, BIN LIN ${ }^{1,2 \#}$, JING-ZU SUN ${ }^{2} \&$ XING-ZHONG LIU ${ }^{1,2^{*}}$ \\ ${ }^{I}$ School of Life Sciences, University of Science and Technology of China, Hefei 230026, Anhui Province, P.R. China \\ ${ }^{2}$ State Key Laboratory of Mycology, Institute of Microbiology, Chinese Academy of Sciences, Beijing 100101, P. R. China \\ "email:liuxz@im.ac.cn \\ " These authors contributed equally to this work.
}

\begin{abstract}
Three ascomycetes, isolated from the body cavity of the scale insect, Aspidiotus sp., collected in Song Mountain, Yanqing, Beijing, China, were identified to be a new species of Knufia. Knufia aspidiotus sp. nov. is introduced in this paper. The species is characterized by slow-growing, dematiaceous and blastic, endogenous conidia in undifferentiated hyphae, as well as darkly pigmented, enlarged multicellular bodies, and is similar to other Knufia species in morphology. Phylogenetic analyses, based on the small ribosomal subunit (SSU) gene and internal transcribed spacer (ITS) region, indicated that Knufia aspidiotus was related to, but clearly distant from other sequenced species in Knufia.
\end{abstract}

Key words: new species, morphology, phylogeny, taxonomy

\section{Introduction}

Species of the genus Knufia are black yeasts, belonging to the family Chaetothyriaceae (Chaetothyriales, Ascomycota). The genus was introduced by Hutchison and Untereiner (1995), and presently comprises $K$. cryptophialidica L.J. Hutchison \& Unter., K. endospora Tsuneda \& Currah, K. perforans (Sterfl.) Tsuneda, Hambl. \& Currah, K. peltigerae (Fuckel) Réblová \& Unter., K. epidermidis (D.M. Li, de Hoog, Saunte \& X.R. Chen) Tsuneda, Hambl. \& Currah, and K. petricola (Wollenz. \& de Hoog) Tsuneda, Hambl. \& Currah (= Phaeococomyces chersonesos Bogom. \& Minter) (Hutchison et al. 1995, Tsuneda et al. 2005, 2011, Réblová et al. 2013, Selbmann et al. 2013, Vicente et al. 2013).

The diagnostic features of Knufia, based on the morphology of type species, $K$. cryptophialidica, are the formation of black, slow-growing colonies and production of conidia from undifferentiated, holoblastic, conidiogenous cells on the hyphae, as well as from phialides (Hutchison et al. 1995). After studying four strains of $K$. cryptophialidica (including the ex-type strain), Tsuneda and Currah (2005), however, concluded that phialidic conidia production was not a constant character. Only the ex-type culture formed phialides, while $K$. endospora lacked phialidic conidiogenesis (Tsuneda et al. 2004, 2011). Comparison of morphological characters of Knufia species in culture indicate (1) slow-growing, black colonies; (2) blastic, and endogenous conidia in undifferentiated hyphae or multicellular bodies; and (3) darkly pigmented, enlarged multicellular bodies are reliable characteristics to differentiate species (Tsuneda et al. 2004, 2005, 2011).

Molecular analyses have recently been applied to the taxonomy and phylogeny of black yeasts (Halici et al. 2010, Nelsen et al. 2011, Feng et al. 2012, Lawrey et al. 2012, Chomnunti et al. 2013). This is because black yeasts are notoriously difficult to identify by morphology alone, due to their lack of significant differentiation, their pleomorphic growth, and their variable modes of conidiogenesis (Untereiner et al. 1995 , Sterflinger 2006). The large and small ribosomal subunit sequences (LSU and SSU) are suitable for placement 


\section{References}

Asensio, L., Lopez-Llorca, L.V. \& Lopez-Jimenez, J.A. (2005) Use of light, scanning electron microscopy and bioassays to evaluate parasitism by entomopathogenic fungi of the red scale insect of palms (Phoenicococcus marlatti Ckll., 1899). Micron 36(2): 169-175.

http://dx.doi.org/10.1016/j.micron.2004.09.004

Bogomolova, E.V. \& Minter, D.W. (2003) A new microcolonial rock-inhabiting fungus from marble in Chersonesos (Crimea, Ukraine). Mycotaxon 86: 195-204.

Chomnunti, P., Thida, W.K.K., Chukeatirote, P., Hyde, K.D., Cai, L., Jones, E.B.G., Kodsueb, R., Hassan, B.A. \& Chen, H. (2012) Phylogeny of Chaetothyriaceae in northern Thailand including three new species. Mycologia 104(2): 382395. http://dx.doi.org /10.3852/11-066

Chomnunti, P., Bhat, D.J., Jones, E.B.G., Chukeatirote, E., Bahkali, A.H. \& Hyde, K.D. (2013) Trichomeriaceae, a new sooty mould family of Chaetothyriales. Fungal Diversity 56: 63-72. http://dx.doi.org /10.1007/s13225-012-0197-2

de Hoog, G.S., Zalar, P., Urzi, C., de Leo, F., Yurlova, N. \& Sterflinger, K. (1999) Relationships of dothideaceous black yeasts and meristematic fungi based on 5.8S and ITS2 rDNA sequence comparison. Studies in Mycology 43: 31-37.

Feng, P.Y., Lu, Q.Y., Najafzadeh, M.J., van den Ende, A.H.G.G., Sun, J.F., Li, R.Y., Xi, L.Y., Vicente, V.A., Lai, W., Lu, C. \& de Hoog, G.S. (2012) Cyphellophora and its relatives in Phialophora: biodiversity and possible role in human infection. Fungal Diversity (In press). http://dx.doi.org /10.1007/s13225-012-0194-5

Foldi, I. (1990) The scale cover. In: Rosen, D. (eds.) Armored Scale Insects: Their Biology, Natural Enemies and Control. Elsevier Science Publishers, Elsevier, Amsterdam, pp. 43-54.

Gueidan, C., Villaseñor, C.R., de Hoog, G.S., Gorbushina, W.A., Untereiner, W.A. \& Lutzoni, F. (2008) A rockinhabiting ancestor for mutualistic and pathogen-rich fungal lineages. Studies in Mycology 61: 111-119. http://dx.doi.org/10.3114/sim.2008.61.11

Halici, M.G., Hawksworth, D.L., Candan, M. \& Turk, A.O. (2010) A new lichenicolous species of Capronia (Ascomycota, Herpotrichiellaceae), with a key to the known lichenicolous species of the genus. Fungal Diversity 40(1): 37-40. http://dx.doi.org/10.1007/s13225-009-0003-y

Hambleton, S., Tsuneda, A. \& Seifert, K. (2002) Knufia cryptophialidica, a close phylogenetic relative of Coniosporium spp. (Ascomycota, incertae sedis). Paper presented at the The 7th International Mycological Congress, Oslo, Norway, 11-17, August.

Hawksworth, D.L. \& Eriksson, O. (1987) Notes on ascomycete systematics. Nos 225-463. Systema Ascomycetum 6: $111-165$.

Henk, D.A. \& Vilgalys, R. (2007) Molecular phylogeny suggests a single origin of insect symbiosis in the Pucciniomycetes with support for some relationships within the genus Septobasidium. American Journal of Botany 94(9): 1515-1526. http://dx.doi.org/10.3732/ajb.94.9.1515

Hutchison, L.J., Untereiner, W.A. \& Hiratsuka, Y. (1995) Knufia cryptophialidica gen. et sp. nov., a dematiaceous hyphomycete isolated from black galls of trembling aspen (Populus tremuloides). Mycologia 87(6): 902-908. http://dx.doi.org/10.2307/3760868

Katoh, K., Kuma, K., Toh, H. \& Miyata, T. (2005) MAFFT version 5: improvement in accuracy of multiple sequence alignment. Nucleic Acids Research 33(2): 511-518. http://dx.doi.org/10.1093/nar/gki198

Lawrey, J.D., Diederich, P., Nelsen, M.P., Freebury, C., Van den Broeck, D., Sikaroodi, M. \& Ertz, D. (2012) Phylogenetic placement of lichenicolous Phoma species in the Phaeosphaeriaceae (Pleosporales, Dothideomycetes). Fungal Diversity 55(1): 195-213. http://dx.doi.org/10.1007/s 13225-012-0166-9

Li, D.M., de Hoog, G.S., Saunte, D.M.L., Van den Ende, A.H.G.G. \& Chen, X.R. (2008) Coniosporium epidermidis sp nov., a new species from human skin. Studies in Mycology 61: 131-136. http://dx.doi.org/10.3114/sim.2008.61.13

Li, D.M. \& Chen, X.R. (2010) A new superficial fungal infection caused by Coniosporium epidermidis. Journal of the American Academy of Dermatology 63(4): 725-727. http://dx.doi.org/10.1016/j.jaad.2009.06.006

Malloch, D. (1981) Moulds: Their isolation, cultivation, and identification. University of Toronto Press (Toronto and Buffalo), Toronto, Ontario, $88 \mathrm{pp}$.

Nelsen, M.P., Lucking, R., Mbatchou, J.S., Andrew, C.J., Spielmann, A.A. \& Lumbsch, H.T. (2011) New insights into 
relationships of lichen-forming Dothideomycetes. Fungal Diversity 51(1): 155-162.

http://dx.doi.org/10.1007/s13225-011-0144-7

Nylander, J. (2008) MrModeltest 2.3 README, Uppsala University, Uppsala, Sweden.

Available from: http://www.abc.se/ nylander/mrmodeltest2/mrmodeltest $2 . h t m l$ (accessed 22 May 2008)

Réblová, M., Untereiner, W.A. \& Réblová, K. (2013) Novel evolutionary lineages revealed in the Chaetothyriales (Fungi) based on multigene phylogenetic analyses and comparison of ITS secondary structure. PLOS ONE 8(5): e63547. http://dx.doi.org/10.1371/journal.pone.0063547

Ruibal, C., Platas, G. \& Bills, G.F. (2008) High diversity and morphological convergence among melanised fungi from rock formations in the Central Mountain System of Spain. Persoonia 21: 93-110. http://dx.doi.org/10.3767/003158508X371379

Saunte, D.M., Tarazooie, B., Arendrup, M.C. \& Hoog, G.S. (2012) Black yeast-like fungi in skin and nail: it probably matters. Mycoses 55(2): 161-167. http://dx.doi.org/10.1111/j.1439-0507.2011.02055.x

Selbmann, L., Isola, D., Egidi, E., Zucconi, L., Gueidan, C., de Hoog, G.S. \& Onofri, S. (2013) Mountain tips as reservoirs for new rock-fungal entities: Saxomyces gen. nov. and four new species from the Alps. Fungal Diversity (In press). http://dx.doi.org /10.1007/s13225-013-0234-9

Sterflinger, K., de Baere, R., de Hoog, G.S., de Wachter, R., Krumbein, W.E. \& Haase, G. (1997) Coniosporium perforans and C. apollinis, two new rock-inhabiting fungi isolated from marble in the Sanctuary of Delos (Cyclades, Greece). Antonie Van Leeuwenhoek International Journal of General and Molecular Microbiology 72(4): 349-363. http://dx.doi.org/10.1023/A:1000570429688

Sterflinger, K. (2006) Black Yeasts and meristematic fungi: ecology, diversity and identification. In: Péter, G. \& Rosa, C.A. (eds.) Biodiversity and Ecophysiology of Yeasts. Springer, Berlin Heidelberg, pp. 501-514.

Swofford, D.L. (2002) PAUP*: phylogenetic analysis using parsimony (*and other methods), version 4.0b10. Sinauer Associates, Sunderland.

Tsuneda, A. \& Currah, R.S. (2004) Knufia endospora, a new dematiaceous hyphomycete from trembling aspen. Reports of the Tottori Mycological Institute 42: 1-9.

Tsuneda, A. \& Currah, R.S. (2005) Pleomorphic conidiogenesis among strains of Knufia cryptophialidica. Canadian Journal of Botany-revue Canadienne De Botanique 83(5): 510-517. http://dx.doi.org/10.1139/B05-029

Tsuneda, A., Hambleton, S. \& Currah, R.S. (2011) The anamorph genus Knufia and its phylogenetically allied species in Coniosporium, Sarcinomyces, and Phaeococcomyces. Botany 89(8): 523-536. http://dx.doi.org/10.1139/B11-041

Untereiner, W.A., Straus, N.A. \& Malloch, D. (1995) A molecular-morphotaxonomic approach to the systematics of the Herpotrichiellaceae and allied black yeasts. Mycological Research 99(8): 897-913.

Untereiner, W.A., Gueidan, C., Orr, M.J. \& Diederich, P. (2011) The phylogenetic position of the lichenicolous ascomycete Capronia peltigerae. Fungal Diversity 49(1): 225-233. http://dx.doi.org/10.1007/s13225-011-0097-x

Vicente, V.A., Najafzadeh, M.J., Sun, J.F., Gomes, R.R., Robl, D., Marques, S.G., Azevedo, C.M.P.S. \& de Hoog, G.S. (2013) Environmental siblings of black agents of human chromoblastomycosis. Fungal Diversity (In press). http://dx.doi.org /10.1007/s13225-013-0246-5

White, T.J., Bruns, T., Lee, S. \& Taylor, J.W. (1990) Amplification and direct sequencing of fungal ribosomal RNA genes for phylogenetics. In: Innis, M.A., Gelfand, D.H., Sninsky, J.J. \& White T.J. (eds.) PCR Protocols: A Giude to Methods and Application. Academic Press, San Diego, USA, pp 315-322.

Wollenzien, U., de Hoog, G.S., Krumbein, W. \& Uijthof, J.M.J. (1997) Sarcinomyces petricola, a new microcolonial fungus from marble in the Mediterranean basin. Antonie Van Leeuwenhoek International Journal of General and Molecular Microbiology 71(3): 281-288. http://dx.doi.org/10.1023/A:1000157803954

Wu, Z., Wang, T., Huang, W. \& Qu, Y. (2001) A simplified method for chromosome DNA preparation from filamentous fungi. Mycosystema 20(4): 575-577. 